\title{
COMPARISON OF RESULTS OBTAINED BY WIDAL AGGLUTINATION TEST \& POLYMERASE CHAIN REACTION AMONG CLINICALLY SUSPECTED TYPHOID FEVER CASES
}

\author{
SHAFINAZ KHAN ${ }^{1}$, MD. RUHUL AMIN MIAH ${ }^{2}$, SHAMMIN HAQUE ${ }^{3}$, CHOWDHURY RAFIA NAHEEN ${ }^{4}$ \\ ${ }^{1}$ Assistant Professor, Department of Microbiology, Dr. Sirajul Islam Medical College and Hospital, Dhaka \\ ${ }^{2}$ Professor, Department of Microbiology, Bangabandhu Shiekh Mujib Medical University, Dhaka \\ ${ }^{3}$ Assistant Professor, Department of Pharmacology, Dr. Sirajul Islam Medical College and Hospital, Dhaka \\ ${ }^{4} \mathrm{MD}$ resident (Thesis part), Department of Microbiology, Bangabandhu Shiekh Mujib Medical University, Dhaka
}

\begin{abstract}
The diagnosis of typhoid fever currently depends on isolation of Salmonella Typhi from blood. The sensitivity of blood culture is very low due to prior antibiotic treatment which is a common practice in Bangladesh. The sensitivity of blood culture also decreases at later stage of the disease. Widal test is the most utilized test in Bangladesh next to blood culture because it is inexpensive, less invasive. But the result of the test is controversial due to false negative \& false positive results in some cases.
\end{abstract}

In this study, a recently introduced polymerase chain reaction-based technique (which has $100 \%$ specificity for $S$. Typhi) was compared with widal test among 80 clinically suspected typhoid fever cases.

Among 80 cases, the respective figures of positivity for PCR \& widal test were $70 \% \& 43.75 \%$ respectively.

It can be concluded that PCR based technique is more sensitive \& much superior to widal for diagnosis of typhoid fever.

Keywords: Typhoid fever; nested PCR; widal test.

(Bangladesh J Physiol Pharmacol 2014;30(2):46-50)

\section{INTRODUCTION}

Typhoid fever, one of the major bacterial infections worldwide, is caused by the human-adapted $S$. enterica serovar Typhi. ${ }^{1}$ Typhoid fever is a major public problem in developing countries like Bangladesh. Current estimation shows that total number of typhoid fever episodes was 13.5 million in $2010 .^{2}$ A case of typhoid fever is defined as a person having one or more of the the following characteristics- prolonged fever; disturbances of bowel function; headache, malaise and anorexia; rose spots on the chest, abdomen and back. ${ }^{3}$ Without effective treatment, typhoid fever has a casefatality rate of $10-30 \%$. This number is reduced to $1-$ $4 \%$ in those receiving appropriate therapy ${ }^{1}$. Results obtained from the laboratory are important in confirming the clinical diagnosis of typhoid and contribute to the effective management and treatment of typhoid cases. ${ }^{4}$

Isolation of the $S$. Typhi remains the most effective diagnostic procedure in suspected typhoid fever cases

Address for correspondence: Dr. Shafinaz Khan, Assistant Professor, Department of Microbiology, Dr. Sirajul Islam Medical College, Dhaka. Tel: 01817084480; E-mail: khan_shafinaz@yahoo.com until today. Delayed results obtained with blood culture ( 2 to 3 days) and decreased Isolation rates due to the widespread practice of early antibiotic administration have limited it's practical use in the diagnosis of typhoid fever. ${ }^{5}$

Widal test is simple \& inexpensive test which is considered next in the value to blood culture in developing countries. Though widal test gives false positive \& false negative results, it is very popular in Bangladesh. Other tests such as Dot EIA, Tubex, ELISA, also has been done but these tests also have some drawbacks. So, efforts have been given to develop more sensitive \& specific tests for the diagnosis of typhoid fever.

Recently, nucleic acid amplification tests such as conventional PCR, nested PCR have been explored for detection of specific gene sequence in clinical samples. It can be used in patients having prior antibiotic treatment where blood culture \& other tests such as widal, Typhi-dot may become false negative.

This study aimed at comparing the results of widal agglutination test which is invariably done in Bangladesh and polymerase chain reaction among suspected typhoid fever cases. 


\section{MATERIALS AND METHODS}

The study was carried out in the Department of Microbiology \& Immunology, Bangabandhu Sheikh Mujib Medical University. Serum samples from a total of 80 cases of clinically suspected typhoid fever were collected and subjected to both widal test \& PCR in the microbiology laboratory.

\section{Specimen collection:}

From each individual included in this study, $4 \mathrm{ml}$ of blood was drawn by vein puncture using disposable syringes. Two $\mathrm{ml}$ of blood was placed in plastic disposable tubes, it was left to stand at room temperature $\left(20-25^{\circ} \mathrm{C}\right)$ to allow it to clot, then the sera was separated by centrifugation for 5 minutes, and kept in a eppendorf tube and stored at $-20^{\circ} \mathrm{C}$ till examination. Two $\mathrm{ml}$ of blood was kept in a EDTA tube for PCR \& stored at $-20^{\circ} \mathrm{C}$ until examination. All sera and reagents were allowed to stand at room temperature before use in the test.

\section{Widal Test}

\section{Principle of the assay}

The widal test measures serum agglutinins against somatic and flagellar antigens. When an antibody combines with a corpuscular antigen (forming part of a cell - e.g. bacteria, or inert part with bound antigen) the cells agglutinate, that means they form clumps (i.e. the clumping of cells such as bacteria in the presence of an antibody. The antibody or other molecule binds multiple particles and joins them, creating a large complex). ${ }^{6}$ Titers greater than 1 in 80 for ' $\mathrm{O}$ ' and 1 in 160 for ' $\mathrm{H}$ ' antigens were taken as cut-off tires for seropositivity.

\section{Assay procedure}

1. Using a pipette, $20 \mu \mathrm{l}$ undiluted serum was taken on 3 $\mathrm{cm}$ diameter circles on white tile.

2. Using a dropper one drop of appropriate well- shaken antigen suspension (TO, TH) obtained from Biotec Laboratories, UK was added to each serum aliquot.

3. Both were mixed by stirring for a few seconds with a wooden applicator stick.

4. The tile was rotated slowly and agglutination was read at one minute.

5. If agglutination occurred, then double dilution of the serum was done and the test was repeated.

\section{Extraction of DNA from blood sample:}

DNA extraction from blood was done according to the procedure done by Nagarajan et al. 2009.' One ml EDTA containing blood was centrifuged by micro centrifuge at $13000 \mathrm{rpm}$ for 5 minutes. Supernatant was discarded. Then one mi $0.2 \%$ Triton X-100 (Sigma,
USA) was added to the pellet. The mixture was vortexed, incubated at room temperature for 10 minutes and centrifuged at $13000 \mathrm{rpm}$ for 10 minutes. Supernatant was discarded. One $\mathrm{ml} 0.2 \%$ Triton $X$ was added to the pellet again, vortexed and centrifuged at $13000 \mathrm{rpm}$ for 10 minutes. Then washed with $1 \mathrm{ml}$ nuclease free water, centrifuged at $13000 \mathrm{rpm}$ for 10 minutes \& supernatant discarded. The pellet was resuspended $30 \mu \mathrm{l}$ nuclease free water. Boiled for 10 minutes at $99^{\circ} \mathrm{C}$ then centrifuged for 3 minutes. Supernatant was used as template for PCR.

\section{Contamination Precautions}

DNA extraction and PCRs were performed in separate rooms, using different sets of pipettes and tips. For further safety, all the reagents used in the PCR were aliquoted, so that an aliquot was used only once and then discarded.

\section{Primer}

Primers which target the flagellin gene of Salmonella typhi which is designed by Song et al. $1993^{8}$ were synthesized on Jena Bioscience, Germany. Oligonucleotides ST1 (5'- ACT GCT AAA ACC ACT ACT$\left.3^{\prime}\right)$ and ST2 (5'- TTAACGCAGTAAAGAGAG-3'), which were used for regular PCR to amplify a $458 \mathrm{bp}$ fragment. For nested PCR, oligonucleotides ST3 (5'- ACT GCT AAA ACC ACT ACT -3') and ST4 (5'TGGAGACTTCGGTCGCGTAG-3') were used to amplify a 343 bp fragment.

\section{PCR Conditions}

For regular PCR, $10 \mu \mathrm{L}$ master buffer contained PCR buffer, $\mathrm{MgCl} 2$, deoxy nucleoside triphosphate obtained from Texas Biogene Inc. USA, $1.5 \mu$ of each primer, 0.2 $\mu \mathrm{l}$ of Taq polymease, $2 \mu \mathrm{L}$ of template are taken in a 0.2 $\mathrm{ml}$ PCR tube. Using a thermal cycler (Applied biosystem 2720 ), the reaction mixture was subjected to 40 cycles of 1 minute each at $94^{\circ} \mathrm{C}, 55^{\circ} \mathrm{C}$ and $72^{\circ} \mathrm{C}$, followed by heating at $72^{\circ} \mathrm{C}$ for 10 minutes. For nested PCR, conditions were the same, except that a 1:5 dilution of amplified product was used as template.

\section{Detection of PCR Products}

A reaction mixture of $10 \mu \mathrm{L}$ was fractionated electrophoretically in $2 \%$ agarose gel containing $0.5 \mu \mathrm{g}$ of ethidium bromide per ml. A positive control representing diluted suspension containing DNA (1:200) from isolate of $S$. typhi, and a negative control without any DNA were also included in each lot.

\section{RESULTS}

Table I shows distribution of sex among the suspected typhoid fever cases. Among 80 cases, male were 52 $(65 \%)$ \& female were 28 (35\%). Male \& female ratio was 1.85: 1 . 
Comparison of Results Obtained by Widal Agglutination Test \& Polymerase Chain Reaction among Clinically Suspected Typhoid Fever Cases

\section{Table - I}

Distribution of suspected typhoid fever cases according to gender.

\begin{tabular}{lcc} 
Sex & $\begin{array}{c}\text { Number of suspected } \\
\text { fever cases }\end{array}$ & Percentage \\
\hline Female & 28 & 35 \\
Male & 52 & 65 \\
\hline Total & 80 & 100 \\
\hline
\end{tabular}

Table II shows age range of the study population. The results of the study showed that the age ranged between (3-48) years. Age distribution of 80 cases showed that majority of the cases $(21.25 \%)$ belonged to the age group of $1-5$ years followed by $(17.5 \%)$ to the age group of 6-10 years group which was not statistically significant $(P>0.05)$.

\section{Table II}

Distribution of the suspected typhoid fever cases according to age

\begin{tabular}{ccc}
$\begin{array}{c}\text { Age } \\
\text { groups }\end{array}$ & $\begin{array}{c}\text { Number of suspected } \\
\text { typhoid fever case }\end{array}$ & Percentage \\
\hline $1-5$ & 17 & 21.25 \\
$6-10$ & 14 & 17.5 \\
$11-15$ & 6 & 7.5 \\
$16-20$ & 11 & 13.75 \\
$21-25$ & 7 & 8.75 \\
$26-30$ & 12 & 15 \\
$>30$ & 13 & 16.25 \\
\hline Total & 80 & 100 \\
\hline
\end{tabular}

Table III shows results of PCR \& widal test performed for the diagnosis of typhoid fever. Among the study population, $56(70 \%)$ cases were positive for $S$. Typhi by PCR \& $35(43.75 \%)$ cases were widal positive. The results of widal test in this study are presented in (table - IV). A total of $18,13,4$ out of 80 cases had significant 0 agglutination titer value $(1: 80,1: 160,1: 320$ respectively) \& therefore regarded as positive. On the other hand, a total of $9,7,15,4$ out of 80 cases had significant $H$ agglutination titer value (1:160, 1:320, $1: 640,1: 1280$ respectively) \& regarded as positive.
Table III

Results of PCR \& widal test performed for the diagnosis of PCR

\begin{tabular}{lll}
\hline \multirow{2}{*}{$\begin{array}{c}\text { Name of the } \\
\text { tests }\end{array}$} & \multicolumn{2}{c}{ Results of the test } \\
\cline { 2 - 3 } & Positive (\%) & Negative (\%) \\
PCR & $56(70)$ & $24(30)$ \\
Widal test & $35(43.75)$ & $45(56.25)$ \\
\hline
\end{tabular}

\section{Table IV}

Anti S Typhi O \& $H$ antibody titers in serum of suspected typhoid fever cases detected by widal test

\begin{tabular}{lccc}
\hline Widal test result & $\begin{array}{c}\text { No. of } \\
\text { suspected } \\
\text { typhoid fever } \\
\text { cases }\end{array}$ & Percentage \\
\hline & $1: 80$ & 18 & 51.4 \\
$\begin{array}{l}\text { Antibody } \\
\text { titers to }\end{array}$ & $1: 160$ & 13 & 37.1 \\
STyphi O & $1: 320$ & 4 & 11.4 \\
& $1: 640$ & 0 & 0 \\
\hline $\begin{array}{l}\text { Antibody } \\
\text { titers to }\end{array}$ & $1: 80$ & 9 & 25.7 \\
STyphi H & $1: 160$ & 7 & 20 \\
\hline
\end{tabular}

Comparison between PCR \& widal test for the diagnosis of typhoid fever are presented in (Table-V).

Among the study population, 29 (36.3\%) cases were both test (PCR \& widal) positive \& 18 (22.5\%) cases were both test negative. Six cases were widal positive but negative by PCR. Twenty seven cases were PCR positive but widal negative.

\section{Table V}

Comparison between PCR \& widal test for diagnosis of typhoid fever among the study population

\begin{tabular}{|c|c|c|c|}
\hline \multirow{2}{*}{$\begin{array}{c}\text { Results of } \\
\text { PCR }\end{array}$} & \multicolumn{2}{|c|}{ Results of widal test } & \multirow{2}{*}{$\begin{array}{c}\text { Total } \\
(\%)\end{array}$} \\
\hline & $\begin{array}{c}\text { Positive } \\
(\%)\end{array}$ & $\begin{array}{c}\text { Negative } \\
(\%)\end{array}$ & \\
\hline Positive & $29(36.3)$ & $27(33.8)$ & $56(70)$ \\
\hline Negative & $6(7.5)$ & $18(22.5)$ & $24(30)$ \\
\hline Total & $35(43.8)$ & $45(56.3)$ & $80(100)$ \\
\hline
\end{tabular}




\section{DISCUSSION}

Typhoid fever is a major health problem causing significant morbidity \& mortality in developing country till today due to poor sanitary condition. The study shows that majority (52\%) of the suspected typhoid fever patients was male $\&$ the male female ratio was 1.82. Both sex can be affected by typhoid fever. This findings correlate with the findings reported in several studies in Bangladesh by where $(55 \%)^{9}$ and $(54 \%)^{10}$ typhoid fever patients were male. The higher frequency of infection with typhoid fever among males may be attributed to socio-community nature of Bangladeshi people which makes men undergone the responsibility of working and eventually are in great contact with the pathogens rather than the women. High percentage of infection $(21.25 \%)$ occurs in the age group of $1-5$ years which is similar with the findings of some studies done in Bangladesh. ${ }^{9,10}$ Infection can occur at any age but the results of several studies showed that the prevalence of typhoid fever in children of under 5 years were much higher than other age group. ${ }^{11}$

The diagnosis of typhoid fever on the basis of clinical feature is difficult because they are also present in other febrile illness. Widal test is the most utilized test which is used in Bangladesh. Single-tube widal test was applied in this study. Originally widal test was recommended using paired sera, 1-2 weeks apart \& demonstrating four-fold or greater rise of antibody titer. However, in typhoid fever, a rise in titer between acute and convalescent sera is not always demonstrable even in blood culture confirmed cases, owing to the natural history of the infection, prior antibiotic administration or late presentation to the hospital. Patient management decisions cannot be put off for the results of convalescent phase sera and for all practical purposes, a treatment decision must be made on the basis of a single tube widal test. ${ }^{12}$

There is no consensus in literatures which shows guideline about the diagnostic criteria for interpreting widal test. Widal test interpretation in endemic areas like Bangladesh is difficult because majority of healthy individual has detectable antibodies. There is controversy about the predictive value of $\mathrm{O} \& \mathrm{H}$ antibodies for diagnosis of enteric fever. ${ }^{13}$ Several studies show that a raised $O$ agglutinin is of slightly greater diagnostic value than a raised $\mathrm{H}$ agglutinin because this antibody decline early after acute infection. ${ }^{13,1}$ In this study the high titres ( $>1 / 80$ for Salmonella typhi " $O$ " and $>1 / 160$ for salmonella typhi " $\mathrm{H}$ " antigens) in the Widal test performed on single acute-phase sera was considered as significant and diagnostic. According to this criteria, 35 (43.75\%) cases were widal positive.

Another diagnostic method for diagnosing typhoid fever cases such as nested PCR has been recently introduced. Several studies showed that PCR technique offers highly specific, sensitive and reasonably quick diagnostic modality. ${ }^{8,15}$ Even 1-5 bacteria/ml can be detected with absolute specificity within 1-2 days. ${ }^{13}$ We decided to check this theoretical promise of PCR in the actual situation and compare it with widal test.

We used flagellin gene to detect S. Typhi by PCR, because flagellin gene of $\mathrm{S}$. Typhi has unique nucleotide sequences in hypervariable region VI which are different from those sequence in other strains of Salmonella. ${ }^{8}$ The result shows that $56(70 \%)$ suspected cases were positive for $S$. Typhi by PCR. The results of this study agreed with the results of similar study done by Haque et al. 1999 who reported that a significant difference has been noticed between widal test and PCR for detection of typhoid fever. ${ }^{16}$ Additionally, Prakash et al. 2005 has found that a considerable difference among widal and PCR for investigating typhoid fever, also found that PCR was not only relatively rapid but also more accurate than traditional method (widal test). ${ }^{17}$

This study showed that $6(7.5 \%)$ cases were widal positive but PCR negative. Among these 6 cases, 2 were diagnosed as dengue fever, 1 was diagnosed as viral hepatitis later. This positive widal test might be due to cross reaction by non-typhoidal antigens in some organisms (malaria, dengue, miliary tuberculosis, endocarditis, chronic liver disease, brucellosis, etc). ${ }^{6}$

In this study, 27 (33.8\%) cases were PCR positive but widal negative. Possible hypotheses put forward to explain this phenomenon are prior use of antibiotics, the existence of less immunogenic strains of $S$. Typhi, reduced immunity in some patients from severe nutritional hypoproteinaemia. ${ }^{18}$ Without PCR, these cases would have been missed.

\section{CONCLUSION}

Typhoid fever is endemic in Bangladesh, so a local titer is present in healthy population which should be reviewed yearly. Although, widal test is a popular test in Bangladesh, it can give false negative or false positive results which lead us to a wrong diagnosis resulting initiation of inappropriate treatment. As a result, the chance of development of multidrug resistant strains increase which increases the cost of treatment \& patient's sufferings. PCR can overcome the drawbacks of widal test as it is positive in cases where widal test is false negative. It is negative in cases where widal is false positive $\&$ can prevent the initiation of unnecessary treatment. So, it can be concluded that PCR is accurate, precise, objective and well suitable for routine determination of typhoid fever.

\section{REFERENCES}

1. Crump JA, Mintz LS. The global burden of typhoid fever. Bull World Health Org 2004; 82: 346-53.

2. Buckle GC, Christa L, Walker F, Black RE. Typhoid fever and paratyphoid fever: Systemic review to estimate global morbidity and mortality for 2010. J Global Health 2012; 2: 1-9. 
3. World Health Organization, Background document: The diagnosis, treatment and prevention of typhoid fever. World Health Organization; 1988. Available at http://whqlibdoc.who.int/hq/2003/WHOV\%26B_03.07.pdf (Accessed 02.05.2013).

4. Ismail A. New advances in the diagnosis of typhoid and detection of typhoid carriers. Malaysian J Med Sci 2000; 7: 3-8.

5. Tupasi TE, Aquino RL, Mendoza MT, Tuazon CU and Lolekha S. Clinical Application of the widal test. Phil J Microbiol infect Dis 1991; 20: 23-6.

6. Olopoenia LA, King AL. Widal agglutination test 100 years later: still plagued by controversy, Postgrad Med J 2000; 76: 80-84.

7. Nagarajan AG, Karnam G, Lahiri A, Allam US, Chakravortty D. Reliable means of diagnosis and serovar determination of blood borne salmonella strains. Quick PCR Amplification of Unique Genomic Loci by Novel primer sets, J Clin Microbiol 2009; 47: 2435-2441.

8. Song $\mathrm{JH}$, Cho $\mathrm{H}$, Park MY, Na DS, Moon HB, Pai CH. Detection of Salmonella Typhi in the blood of patients with typhoid fever by polymerase chain reaction. J Clin Microbial 1993; 31, 14391443.

9. Begum Z. Comparison among the different diagnostic procedures for early \& rapid diagnosis of typhoid fever, M.Phil thesis (2008). Dhaka University. (Online) Available at:

http://www.mmc.gov.bd/downloadable\%20file/Rapid\%20Diagn osis\%20of\%20Typhoid\%20Fever\%20by\%20Dr.\%20Johra\%20 Begum.pdf. [Accessed 03.05.2013]

10. Sultana S, Comparison of different test methods including polymerase chain reaction for early and reliable diagnosis of typhoid fever, M.Phil. Thesis (2012), B.S.M.M.U. (Online) Available at: http://www.mmc.gov.bd/downloadable\%20file/typhoid\%20fev er\%20by\%20PCR\%20by\%20Dr.\%20Safia\%202012.pdf. [Accessed 05.04.2013]

11. Brooks AW, Hossain A, Goswami D, Sharmin AT, Nahar K, Alam $\mathrm{K}$ et al. Bacteraemic Typhoid fever in children in an urban slum, Bangladesh. Emerg Infect Dis 2005; 11: 326-329.

12. Mohanty SK. Single and unpaired sera Tube widal agglutination test in Enteric fever. Saudi J Gasteroenterology 2007; 13: 213.

13. Kundu R, Ganguly N, Ghosh TK, Yewale VN, Shah RC, Shah NK. IAP Task Force Report: Diagnosis of Enteric Fever in Children. Ind Pediatrics 2006; 43: 875-83.

14. Pang T, Puthucherary SD. Significance and value of widal test in the diagnosis of typhoid fever in an endemic area. J Clin Pathol 1983; 36: 417-475.

15. Hashimoto $Y$, Itho $Y$, Fujinaga $Y$, Khan $A Q$, Sultana $F$, Miyake $M$, Hirose $K$, Yamamoto $H$, Ezaki $T$. Development of nested PCR based on the ViaB sequence to detect Salmonella typhi. ] Clin Microbiol 1995; 33: 775.

16. Haque A, Ahmed J, Qureshi JA. Early detection of typhoid by polymerase chain reaction. Ann Saudi Med 1999; 19, 337-340.

17. Prakash $\mathrm{P}$, Mishra OP, Singh AK et al. Evaluation of nested PCR in diagnosis of typhoid fever. J Clin Microbiol 2005; 43: 431432.

18. Noorbakhsh $\mathrm{S}$, Rimaz $\mathrm{S}$, Rahbarimanesh AA, Mamishi $\mathrm{S}$. Interpretation of the widal test in Infected Children. Iranian J Publ Health 2003; 32: 35-37. 